\title{
IMPLEMENTASI PENDIDIKAN MATEMATIKA REALISTIK (PMR) UNTUK MENINGKATKAN KEMAMPUAN BERPIKIR KREATIF MATEMATIK DAN KEMANDIRIAN BELAJAR PESERTA DIDIK
}

\author{
THE IMPLEMENTATION OF PENDIDIKAN MATEMATIKA REALISTIK (PMR) TO \\ ImProve Mathematical CREATIVE THINKING ABILITY AND SELF REGULATED \\ LEARNING OF LEARNERS
}

\author{
Dedi Muhtadi' dan Sukirwan ${ }^{2}$ \\ ${ }^{1}$ Pendidikan Matematika, Universitas Siliwangi, Tasikmalaya \\ dedimuhtadi@unsil.ac.id \\ 2 Pendidikan Matematika, Universitas Sultan Ageng Tirtayasa, Banten \\ skbtn309528@yahoo.com
}

\begin{abstract}
Abstrak
Penelitian ini bertujuan untuk menggambarkan pencapaian dan peningkatan kemampuan berpikir kreatif matematik (KBKM) dan kemandirian belajar peserta didik melalui implementasi Pendekatan Matematika Realistik (PMR). Populasi penelitian ini adalah peserta didik SMP Negeri di Kota Tasikmalaya. Sampel penelitian adalah peserta didik kelas VIII yang mewakili satu sekolah level tinggi dan satu sekolah level sedang. Penelitian ini merupakan penelitian kuasi eksperimen dengan desain kelompok kontrol pretes-postes. Instrumen yang digunakan yaitu tes KBKM, skala kemandirian belajar peserta didik, dan lembar observasi. Analisis data menggunakan uji Kruskal Wallis. Dari hasil penelitian disimpulkan: 1) Pencapaian dan peningkatan KBKM kelompok PMR lebih baik dari kelompok PK; dan 2) Pencapaian dan peningkatan kemandirian belajar kelompok PMR lebih baik dari kelompok PK.

Kata Kunci: Kemampuan berpikir kreatif matematik, kemandirian belajar, Pendidikan Matematik Realistik.
\end{abstract}

\begin{abstract}
The purposes of this study are to describe the enhancement and the achievement of students' Mathematical Creative Thinking Skills (MCTS) and Self Regulated Learning (SRL) through implementation of Realistic Mathematics Education (RME) and Conventional Learning (CL). The population of this study were Junior High School students in Tasikmalaya City. The sample of this study were eighth grade students representing the high school level and the medium school level. This research is a quasi-experimental design with pretest-posttest control group. The instrument used is a test MCTS, scale independence of learners, and the observation sheet. Analysis of data using Kruskal Wallis test. The final conclusion: 1) Achievement and improvement of MCTS RME group is better than CL group; and 2) Achievement and improvement of Self Regulated Learning (SRL) RME group is better than CL group.

Keyword: Mathematical creative thinking skills, self regulated learning, Realistic Mathematics Education (RME).
\end{abstract}




\section{Pendahuluan}

Berbicara tentang matematika di sekolah, tidak terlepas dari masalahmasalah yang terdapat di dalamnya. Para guru menyadari bahwa matematika bukanlah termasuk pelajaran yang mudah bagi kebanyakan peserta didik. Matematika seringkali dikeluhkan peserta didik sebagai pelajaran yang sulit dan membosankan, karena matematika diajarkan dengan metode yang kurang menarik dan sulit dimengerti. Umumnya yang terjadi di lapangan, guru menerangkan materi, sementara peserta didik hanya mendengarkan dan mencatat materi yang disampaikan oleh guru. Akibatnya nilai matematika peserta didik lebih rendah dibandingkan dengan pelajaran lainnya. Rendahnya pencapaian belajar peserta didik dalam matematika bukan semata-mata karena materinya yang sulit, tetapi juga disebabkan karena proses pembelajarannya yang kurang menarik dan tidak dapat dimengerti oleh peserta didik.

Isu pembelajaran saat ini adalah pembelajaran yang terpusat pada keterlibatan peserta didik secara aktif. Tetapi, kenyataan di lapangan menunjukkan bahwa pembelajaran di sekolah masih berjalan secara konvensional. Umumnya, banyak guru masih mendominasi pembelajaran, sehingga aktivitas peserta didik cenderung pasif dan berdampak pada pencapaian hasil belajar yang kurang memuaskan. Hal ini terungkap dari hasil kajian Badan Penelitian dan Pengembangan,
Departemen Pendidikan Nasional tahun 2007. Dari hasil kajian tersebut diperoleh beberapa permasalahan yang terjadi di setiap jenjang pendidikan dasar dan menengah, diantaranya yaitu (Depdiknas, 2007): 1) Pelaksanaan pembelajaran di kelas masih konvensional; 2) Metode pembelajaran kurang bervariasi, umumnya masih ceramah dan tanya jawab; dan 3) Kegiatan belajar mengajar kurang mengaktifkan siswa. Hal tersebut didukung oleh pendapat Rohaeti (2010), bahwa pembelajaran di sekolah berfokus pada konten materi dan mengabaikan pengembangan kemampuan berpikir siswa. Berdasarkan hal tersebut, maka diperlukan penggunaan model pembelajaran yang dapat memacu peningkatan kemampuan berpikir kreatif dan kemandirian belajar peserta didik.

Berkaitan dengan kemampuan berpikir kreatif, Ruseffendi (2006) menjelaskan bahwa kreativitas siswa akan tumbuh apabila dilatih melakukan eksplorasi, inkuiri, penemuan dan memecahkan masalah. Sementara, menurut Darr \& Fisher (2004), jika siswa diharapkan menjadi siswa yang mandiri, mereka perlu aktif dan dihadapkan pada kesempatankesempatan yang memungkinkan mereka berpikir, mengamati, dan mengikuti pikiran orang lain.

Salah satu model pembelajaran yang memuat aktivitas-aktivitas eksplorasi, penemuan, pemecahan masalah, dan mengikuti pikiran orang lain yaitu model pembelajaran dengan menggunakan pendekatan Pendidikan Matematika 
Realistik (PMR). Pembelajaran dengan menggunakan pendekatan PMR, dirancang berawal dari permasalahan yang ada di sekitar peserta didik dan berbasis pada pengetahuan yang telah dimilikinya, sehingga diharapkan dapat meningkatkan pemahaman matematika peserta didik. Oleh karena itu, pembelajaran matematika sebaiknya diupayakan bersifat konstekstual, artinya pembelajaran matematika perlu dikelola dengan memperhatikan konteks (lingkungan) kehidupan sehari-hari. Langkah ini sesuai dengan Permendiknas Nomor 22 Tahun 2006 (BSNP, 2006) yang menyatakan bahwa: "Dalam setiap kesempatan, pembelajaran matematika hendaknya dimulai dengan pengenalan masalah yang sesuai dengan situasi". Misalnya, pembelajaran matematika dilaksanakan dengan menggunakan benda-benda atau peristiwa-peristiwa yang berasal dari lingkungan kehidupan peserta didik. Benda-benda atau peristiwa-peristiwa yang berasal dari lingkungan kehidupan peserta didik tersebut dapat digunakan sebagai bahan untuk mengawali pembahasan topik-topik matematika tertentu.

Program pembelajaran dalam kerangka PMR dikembangkan dan diteliti di Belanda sejak tahun 1971 oleh The Freudenthal Institute yang dikenal sebagai Realistic Mathematics Education (RME), yang didasarkan pada gagasan-gagasan Professor Hans Freudenthal yang menyatakan bahwa matematika merupakan aktivitas manusia. Artinya bahwa matematika bukan merupakan suatu subjek yang siap saji untuk peserta didik, melainkan bahwa matematika adalah suatu pelajaran yang dinamis yang dapat dipelajari dengan cara mengerjakannya.

Kuiper \& Knuver (Tim MKPBM, 2003:143) mengemukakan beberapa penelitian pendahuluan di beberapa negara yang menunjukkan bahwa pembelajaran dengan menggunakan pendekatan matematika realistik dapat membuat:

1. Matematika lebih menarik, relevan, dan bermakna, tidak terlalu formal dan tidak terlalu abstrak.

2. Mempertimbangkan tingkat kemampuan siswa.

3. Menekankan belajar matematika pada 'learning by doing'.

4. Memfasilitasi penyelesaian masalah matematika tanpa menggunakan penyelesaian (algoritma) yang baku.

5. Menggunakan konteks sebagai titik awal pembelajaran matematika.

Keberhasilan pembelajaran dalam pengertian tercapainya standar kompetensi, sangat bergantung pada kemampuan guru mengolah pembelajaran yang dapat menciptakan situasi yang memungkinkan peserta didik untuk mengembangkan kemampuan berpikir kreatif matematik yang merupakan titik awal berhasilnya pembelajaran. Beberapa penelitian telah dilakukan untuk meningkatkan kemampuan berpikir kreatif dengan berbagai model pembelajaran, diantaranya: penelitian yang dilakukan 
oleh Hasanah (2011), Moma, Kusumah, Sabandar \& Dahlan (2013), Kurniati (2014), dan Fatah, Suryadi, Sabandar, \& Turmudi (2016). Kemampuan berpikir kreatif matematik merupakan bagian keterampilan hidup yang perlu dikembangkan terutama dalam menghadapi era informasi dan suasana bersaing yang semakin ketat (Sumarmo, 2013:4). Oleh karena itu kemampuan berpikir kreatif matematik sangat penting dimiliki peserta didik untuk menghadapi perubahan-perubahan dan mampu menghasilkan sesuatu yang baru di masa depan.

Kemampuan lain yang harus dimiliki peserta didik selain berpikir kreatif adalah kemampuan untuk mandiri, yaitu sikap dan perilaku yang tidak mudah bergantung pada orang lain dalam menyelesaikan tugas-tugas. Hasil studi Ratnaningsih (Sumarmo, 2013: 118) mengatakan bahwa semakin tinggi kemampuan berpikir kreatif matematik peserta didik, maka semakin tinggi pula kemandirian belajar matematik peserta didik, begitu juga sebaliknya. Menurut Paris dan Winograd (Sumarmo, U., 2013:110) karakteristik yang termuat dalam sikap mandiri adalah kesadaran berpikir, penggunaan strategi, dan motivasi yang berkelanjutan.

Berdasarkan latar belakang masalah yang dikemukakan dan hasil-hasil penelitian yang telah dilakukan sebelumnya, maka salah satu alternatif pembelajaran untuk mengatasi permasalahan kemampuan berpikir kreatif matematik dan kemandirian belajar peserta didik adalah dengan menggunakan pembelajaran dengan pendekatan pendidikan matematika realistik (PMR). Oleh karena itu penelitian ini bertujuan untuk menggambarkan pencapaian dan peningkatan kemampuan berpikir kreatif matematik (KBKM) dan kemandirian belajar peserta didik sebagai implementasi Pembelajaran Matematika Realistik (PMR) dan Pembelajaran Konvensional (PK).

Berpikir kreatif dipandang sebagai suatu proses yang digunakan ketika seorang individu mendatangkan atau memunculkan suatu ide baru. Ide baru tersebut merupakan gabungan dari ide-ide sebelumnya yang belum pernah diwujudkan (Infinite Innovation Ltd, 2001). Hal ini sejalan dengan pendapat Coleman dan Hammen (Sumarmo, 2013:202) yang menyatakan, "berpikir kreatif merupakan cara berpikir yang menghasilkan sesuatu yang baru dalam konsep, pengertian, penemuan, dan karya seni".

Pengertian ini lebih memfokuskan pada proses individu untuk memunculkan ide baru yang merupakan gabungan ide-ide sebelumnya yang belum diwujudkan atau masih dalam pemikiran. Pengertian berpikir kreatif ini ditandai dengan adanya ide baru yang dimunculkan sebagai hasil dari proses berpikir tersebut. Berdasarkan pendapat-pendapat tersebut, maka dapat disimpulkan bahwa berpikir kreatif adalah suatu kegiatan mental yang digunakan seseorang untuk membangun, menghasilkan ide atau gagasan yang baru.

Alvino (Sumarmo, 2013:201) menyatakan terdapat empat komponen 
dalam berpikir kreatif, yaitu sebagai berikut:

1. Kelancaran (fluency) membuat berbagai ide.

2. Kelenturan (flexibility) kelihaian memandang ke depan dengan mudah.

3. Keaslian (originality) menyusun sesuatu yang baru.

4. Elaborasi (elaboration) membangun sesuatu dari ide-ide lainnya.

Selanjutnya Munandar (Sumarmo, 2013:201) merinci keempat komponen tersebut, sebagai berikut:

1. Kelancaran (fluency): mencetuskan banyak ide, jawaban, cara atau saran untuk melakukan berbagai hal.

2. Kelenturan (flexibility): menghasilkan gagasan, jawaban, atau pertanyaan yang bervariasi, melihat suatu masalah dari sudut pandang yang berbeda-beda, mampu mengubah cara pendekatan atau cara pemikiran.

3. Keaslian (originality): melahirkan ungkapan yang baru dan unik, memikirkan cara yang tidak lazim, membuat kombinasi-kombinasi yang tidak lazim dari bagian-bagiannya.

4. Elaborasi (elaboration): memperkaya dan mengembangkan suatu gagasan atau produk, menambah atau memperinci detil-detil dari suatu obyek, gagasan, atau situasi sehingga menjadi lebih menarik.

Berdasarkan pendapat-pendapat tersebut, maka dapat disimpulkan bahwa kemampuan berpikir kreatif matematik merupakan kemampuan berpikir untuk menghasilkan ide-ide baru dan orisinil dalam menyelesaikan suatu masalah matematik atau dalam menanggapi situasi matematik tertentu yang ditandai dengan adanya aspek kelancaran, kelenturan, keaslian, dan elaborasi.

Kemandirian belajar merupakan arti dari kata Self-Regulated Learning. Zimmerman adalah akademik pertama yang mengusulkan konstruk self regulated learning dalam psikologi pendidikan. Zimmerman (Cheng, 2011) menjelaskan bahwa self regulated learning merupakan suatu proses pembelajaran dimana peserta didik menggunakan keterampilan pengaturan diri (self-regulatory), seperti penilaian diri (self-assessing), selfdirecting, pengontrolan (controlling) dan penyesuaian (adjusting), dalam rangka untuk memperoleh pengetahuan. Selanjutnya menurut Cheng (2011), dalam proses kemandirian belajar, peserta didik memantau dan menyesuaikan strategi belajar mereka. Pemantauan kegiatan termasuk memeriksa isi studi, menilai kesulitan pembelajaran, menilai kemajuan, dan memprediksi hasil belajar.

Pendapat lain dikemukakan Wolters, Pintrich, \& Karabenick (2003) bahwa kemandirian belajar adalah suatu proses konstruktif dan aktif dimana peserta didik menentukan tujuan belajarnya, mencoba untuk memonitor, mengatur, dan mengendalikan kognisi, motivasi, dan perilaku dengan dibimbing dan dibatasi oleh tujuan dan karakteristik kontekstual dalam lingkungan. Pendapat ini mengandung kesamaan dengan pendapat 
Cheng (2011) dan Zimmerman (Cheng, 2011) bahwa kemandirian belajar mengandung proses pemantauan kegiatan belajar, evaluasi terhadap hasil belajar atau kesulitan dalam belajar dan penyesuaian diri. Hal ini sejalan dengan pendapat yang diungkapkan Zumbrunn, Tadlock \& Roberts (2011) bahwa kemandirian belajar adalah proses yang membantu peserta didik dalam mengelola pikiran, perilaku, dan emosi mereka agar berhasil mengarahkan belajar mereka.

Zimmerman, Bonner, \& Kovach (Cheng, 2011) mengusulkan siklus model kemandirian belajar yang terdiri dari empat proses berkorelasi: monitoring dan evaluasi diri, penetapan tujuan dan perencanaan strategis, implementasi strategi dan monitoring, serta monitoring hasil. Tahap pertama yaitu evaluasi diri dan monitoring. Pada tahap ini individu mengevaluasi efektivitas pribadi mereka berkaitan dengan tugas belajar yang spesifik. Tahap kedua adalah penetapan tujuan dan perencanaan strategis, yang meliputi analisis tugas belajar, penetapan tujuan spesifik, pembuatan rencana dan strategi pembelajaran. Tahap ketiga yaitu memantau implementasi strategi dan memonitor keakuratan mereka dalam menerapkan strategi khusus ini. Tahap terakhir adalah monitoring hasil, dimana peserta didik menilai efektivitas pembelajaran sendiri berdasarkan hasil belajar dan proses yang dilakukan.

Dari berbagai pendapat di atas dapat disimpulkan bahwa kemandirian belajar adalah suatu proses untuk memperoleh pengetahuan dengan menggunakan berbagai strategi kognitif dan metakognitif untuk melakukan pengontrolan dan pengaturan dalam belajarnya. Peserta didik yang memiliki kemandirian dalam belajar akan merencanakan untuk belajar didasarkan pada hasil evaluasi hasil dan proses sebelumnya, memilih strategi dan melaksanakan perencanaan yang sudah dibuat, melaksanakan pemantauan atau pengontrolan diri terhadap tindakan, sikap, dan motivasi, dan melakukan evaluasi terhadap hasil belajarnya.

Kata realistik mengacu pada pendekatan dalam pendidikan matematika yang telah dikembangkan di Nederlands (Belanda) sejak tahun 1971 yang disebut dengan Realistic Mathematics Education (RME). RME dikembangkan berdasarkan pandangan tentang matematika, bagaimana peserta didik belajar matematika, dan bagaimana seharusnya matematika diajarkan. Pendekatan tersebut dipengaruhi oleh pemikiran Hans Freundenthal, seorang pendidik dan sekaligus ahli matematika, yang beranggapan bahwa matematika merupakan suatu aktivitas manusia. la menyatakan bahwa peserta didik tidak bisa dianggap sebagai penerima pasif dari pembelajaran matematika, tetapi pembelajaran matematika hendaknya memberikan kesempatan kepada peserta didik untuk menemukan kembali pengetahuan matematika dengan memanfaatkan berbagai kesempatan dari situasi nyata yang dialami peserta didik. 
Mempelajari berbagai situasi yang dapat menggambarkan beragam permasalahan merupakan suatu pengalaman pembelajaran yang berharga bagi peserta didik. Diawali dengan menghubungkan matematika dengan situasi nyata, memberikan kesempatan untuk mengembangkan model-model matematika dan memahami lebih banyak hal pada tingkat yang lebih tinggi. Modelmodel yang berkembang berdasarkan kemampuan dan aktivitas peserta didik dapat menghantarkan mereka ke tingkat pemahaman yang lebih tinggi.

Menurut Gravemeijer (1994: 90) terdapat tiga prinsip kunci pembelajaran matematika realistik, yaitu: (1) Guided Reinvention/Progressive Mathematizing (menemukan kembali dengan bimbingan/matematisasi progressif), (2) Didactical Phenomenologi (fenomena didaktik), dan (3) Self-developed Models (model yang dibangun sendiri oleh siswa)

Dalam RME, dunia nyata (real world) dapat dimanfaatkan sebagai titik awal pengembangan ide dan konsep matematika. Blum \& Niss (Hadi, S., 2010: 2) menyatakan: "Dunia nyata adalah segala sesuatu di luar matematika seperti pada pelajaran lain selain matematika, atau kehidupan sehari-hari dan lingkungan sekitar kita". Sementara itu, De Lange (Hadi, S., 2010: 2) menyatakan, "Dunia nyata sebagai suatu dunia yang konkret yang disampaikan kepada siswa melalui aplikasi matematika". Berawal dari sini dapat dikembangkan proses pembelajaran matematika berdasarkan situasi yang dipahami, berhubungan dengan siswa dan dekat dengan lingkungan peserta didik. Hal itu dapat digambarkan dengan skema berikut.

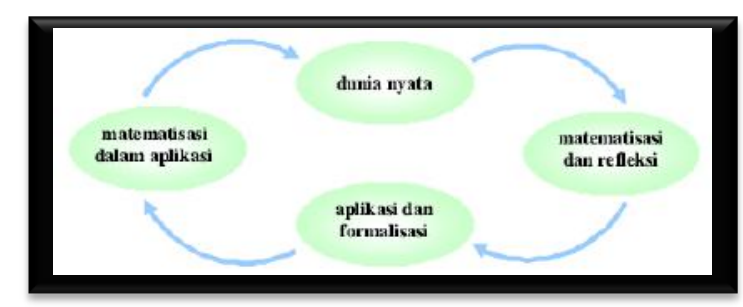

Gambar 1. Konsep Matematisasi De Lange (Hadi, S., 2010: 3).

Skema proses pembelajaran seperti digambarkan di atas menunjukkan bahwa pembelajaran merupakan suatu siklus yang menempatkan suatu proses sebagai salah satu poin utama. Artinya proses lebih diutamakan dibandingkan produk yang dihasilkan.

\section{Metode}

\section{A. Desain Penelitian}

Penelitian ini merupakan penelitian kuasi eksperimen dengan desain kelompok kontrol pretes - postes.

\section{B. Populasi dan Sampel}

Populasi dalam penelitian ini yaitu peserta didik SMP Negeri di Kota Tasikmalaya, Jawa Barat. Sampel adalah peserta didik kelas VIII dari sekolah yang mewakili sekolah level tinggi dan level sedang. Pemilihan sekolah dilakukan secara acak dari seluruh SMP Negeri yang ada di Kota Tasikmalaya. Dari tiap level sekolah dipilih dua kelas secara acak, satu kelas menggunakan PMR dan satu kelas menggunakan PK. Penentuan level 
sekolah, didasarkan pada skor akreditasi dari Badan Akreditasi Nasional.

\section{Instrumen Penelitian}

Instrumen yang digunakan terdiri dari tes KBKM, skala kemandirian belajar, dan lembar observasi. Materi tes KBKM disesuaikan dengan materi yang diberikan pada saat penelitian, yaitu materi kelas VIII semester 1 sesuai dengan kurikulum yang digunakan pada tahun pelajaran 2015/2016 yang terdiri dari relasi dan fungsi, persamaan garis lurus, dan sistem persamaan linier dua variabel. Berdasarkan hasil uji coba diperoleh bahwa tes valid dan reliabel.

Besarnya pencapaian KBKM dan kemandirian belajar peserta didik diperoleh dari skor akhir KBKM dan kemandirian belajar. Untuk menghitung besarnya peningkatan digunakan formula yang dikembangkan oleh Meltzer (2002).

\section{Hasil dan Pembahasan}

\section{A. Pencapaian dan Peningkatan Kemampuan Berpikir Kreatif Matematik}

Untuk menguji perbedaan rerata pencapaian dan peningkatan kemampuan berpikir kreatif matematik antara peserta didik yang mendapatkan PMR dan PK dilakukan uji Kruskal-Wallis. Hal tersebut karena tidak setiap kelompok mempunyai pencapaian dan peningkatan kemampuan berpikir kreatif matematik yang berdistribusi normal. Hasil pengujian pencapaian kemampuan berpikir kreatif matematik disajikan pada Tabel 1.

Tabel 1.

\begin{tabular}{ccccc}
\multicolumn{5}{c}{ Hasil Pengujian Perbedaan Pencapaian } \\
Kemampuan Berpikir Kreatif \\
\hline Model & $\begin{array}{c}\text { Rata-rata } \\
- \\
(\bar{x})\end{array}$ & $\begin{array}{c}\text { Kruskal- } \\
\text { Wallis }\end{array}$ & Sig. & $\mathrm{H}_{0}$ \\
\hline PMR & 41,16 & 47,39 & 0,000 & Ditolak \\
\hline PK & 26,83 & & & \\
\hline
\end{tabular}

Keterangan: Skor Maksimal Ideal 56

Berdasarkan Tabel 1, minimal salah satu rata-rata pencapaian kemampuan berpikir kreatif matematik menunjukkan perbedaan. Selanjutnya dari hasil pengujian dengan uji Multiple Comparissons Between Treatments disimpulkan bahwa pencapaian kemampuan berpikir kreatif matematik peserta didik yang mendapat PMR lebih baik daripada peserta didik yang mendapat PK.

Selanjutnya, hasil pengujian peningkatan kemampuan berpikir kreatif matematik disajikan pada Tabel 2.

Tabel 2.

Hasil Pengujian Peningkatan Kemampuan Berpikir Kreatif

\begin{tabular}{ccccc}
\hline Model & $\begin{array}{c}\text { Rata-rata } \\
\bar{x})\end{array}$ & $\begin{array}{c}\text { Kruskal- } \\
\text { Wallis }\end{array}$ & Sig. & $\mathrm{H}_{0}$ \\
\hline PMR & 0,70 & 55,236 & 0,000 & Ditolak \\
\hline PK & 0,40 & & \\
\hline
\end{tabular}

Berdasarkan Tabel 2, minimal salah satu rata-rata peningkatan kemampuan berpikir kreatif matematik menunjukkan perbedaan. Selanjutnya dari pengujian dengan menggunakan uji Multiple Comparissons Between Treatments disimpulkan bahwa peningkatan kemampuan berpikir kreatif peserta didik yang mendapat PMR lebih baik daripada peserta didik yang mendapat PK. 


\section{B. Pencapaian dan Peningkatan Kemandirian Belajar Peserta Didik}

Pengujian perbedaan rerata pencapaian dan peningkatan kemandirian belajar antara peserta didik yang mendapatkan PMR dan PK digunakan dengan uji KruskalWallis. Hasil pengujian perbedaan pencapaian kemandirian disajikan pada Tabel 3.

Tabel 3.

Hasil Pengujian Perbedaan Pencapaian Kemandirian Belajar

\begin{tabular}{ccccc}
\hline Model & $\begin{array}{c}\text { Rata-rata } \\
(\bar{x})\end{array}$ & $\begin{array}{c}\text { Kruskal- } \\
\text { Wallis }\end{array}$ & Sig. & $\mathrm{H}_{0}$ \\
\cline { 1 - 2 } $\mathrm{PMR}$ & 158,32 & \multirow{2}{*}{19,29} & 0,000 & Ditolak \\
\hline PK & 145,32 & & \\
\hline \multicolumn{4}{l}{ Keterangan: Skor Maksimal Ideal 222 }
\end{tabular}

Berdasarkan Tabel 3, minimal salah satu rata-rata pencapaian kemandirian belajar menunjukkan perbedaan. Berdasarkan hasil pengujian dengan uji Multiple Comparissons Between Treatments disimpulkan bahwa pencapaian kemandirian belajar peserta didik yang mendapatkan PMR lebih baik daripada peserta didik yang mendapat PK.

Selanjutnya dilakukan uji perbedaan peningkatan kemandirian belajar peserta didik yang disajikan pada Tabel 4.

Tabel 4.

Hasil Pengujian Perbedaan Peningkatan Kemandirian Belajar

\begin{tabular}{|c|c|c|c|c|}
\hline Model & $\begin{array}{c}\text { Rata-rata } \\
-\bar{x})\end{array}$ & $\begin{array}{c}\text { Kruskal- } \\
\text { Wallis }\end{array}$ & Sig. & $\mathrm{H}_{0}$ \\
\hline PMR & 0,24 & \multirow{2}{*}{52,18} & \multirow{2}{*}{0,000} & \multirow{2}{*}{ Ditolak } \\
\hline PK & 0,11 & & & \\
\hline
\end{tabular}

Berdasarkan Tabel 4, minimal salah satu rata-rata peningkatan kemandirian belajar matematika peserta didik menunjukkan perbedaan. Berdasarkan hasil pengujian dengan uji Multiple Comparissons Between Treatments disimpulkan bahwa peningkatan kemandirian belajar peserta didik yang mendapat PMR lebih baik daripada peserta didik yang mendapat PK.

\section{Penutup}

Berdasarkan hasil penelitian diperoleh kesimpulan sebagai berikut:

Pencapaian dan peningkatan KBKM peserta didik yang mendapat PMR lebih baik daripada peserta didik yang mendapat PK.

Pencapaian dan peningkatan kemandirian belajar peserta didik yang mendapatkan PMR lebih baik daripada peserta didik yang mendapat PK.

Beberapa saran yang perlu diperhatikan bagi guru dalam menerapkan PMR yang mendukung terhadap peningkatan kemampuan berpikir kreatif matematik dan kemandirian belajar adalah sebagai berikut.

Masalah kontekstual memiliki peran sentral dalam PMR. Berkenaan dengan hal ini guru harus menciptakan situasi masalah yang memiliki karakteristik: (1) bisa diorganisasi menjadi masalah matematik, (2) mudah ditafsirkan dengan konsep matematik tertentu, dan (3) menciptakan beragam ide atau solusi matematik.

\section{DAFTAR PUStaka}

Badan Standar Nasional Pendidikan. (2010). Paradigma pendidikan nasional abad XXI. Jakarta: BSNP. 
Bakker, A., \& Gravemeijer. (2006). An historical phenomenology of mean and median. Educational Studies in Mathematics, 62, hlm. 149-168.

Bybee, R.W., Taylor, J. A., Gardner, A., Scotter P.V., Powel, J.C., Westbrook, A., \& Landes, N. (2006). The BSCS $5 E$ instructional model Origins and effectiveness. [Online]. Diakses dari http://bscs.org/sites/default/files/ leg acy/BSCS 5E Instructional ModelFull Report.pdf.

Cheng, Eric, C.K. (2011). The role selfregulated learning in enhancing learning. The International Journal of Research and Review, 6(1), 1- 16. [Online]. Diakses dari http://repository.lib.ied.edu.hk/pubda ta/ir/link/pub/A1 V6.1 TIJRR.pdf

Darr, C \& Fisher, J. (2004). Self-regulated learning in Mathematics class. [Online]. Diakses dari www.arb.nzcer.org.nz/nzcer3/researc h/Maths/ 2004SRL thinkingmodels.htm.

Departemen Pendidikan Nasional. (2007). Kajian kebijakan kurikulum mata pelajaran Matematika. Jakarta: Badan Penelitian dan Pengembangan Pusat Kurikulum Depdiknas.

Depdiknas (2006). Peraturan Menteri Pendidikan Nasional Republik Indonesia (Permendiknas) Nomor 22 Tahun 2006 Tentang Standar Isi Sekolah Menengah Pertama. Jakarta: Depdiknas.

De Lange, J. (1987). Mathematics Insight and Meaning. Utrecht: OW \& OC.
Ergin, I. (2012). Constructivist approach based 5E model and usability instructional physics. Latin-American Journal of Physics Education, 6(1), 14 -20 .

Fatah, A., Suryadi, D., Sabandar, J. \& Turmudi. (2016). Open-ended Approach: an Effort in Cultivating Students' Mathematical Creative Thinking Ability and Self-esteem in Mathematics. Journal on Mathematics Education, 7( 1), 11-20.

Freudenthal. (1983). Didactical phenomenology of mathematical structures. Dordrecht: Reidel.

Gandhi H. \& Varma, M. (2010). Strategic content learning approach to promote self-regulated learning in mathematics. Poceedings of epiSTME 3.

Gravemeijer, K. (1994). Developing Realistic Mathematics Education. Utrecht: Freudenthal Institute.

Hadi, S. (2010). Introduction to Realistic Mathematics Education. Bahan ajar Diklat Enhancing mathematics Learning in Primary School Using Realistic Mathematic Education. Yogyakarta: SEAMEO Regional Centre for QITEP in Mathematics.

Hasanah, A. (2011). Peningkatan kemampuan berpikir kritis dan kreatif matematis siswa Sekolah Menengah Atas melalui pendekatan Kontekstual berbasis intuisi. Unpublished Dissertation. Bandung: SPs Universitas Pendidikan Indonesia.

Infinite Innovation. Ltd. (2001). Creativity and Creative Thinking. [Online] Tersedia: 
http://www.brainstroming.co.uk/tutor ials/tutorialcontent.html1

Kurniati. (2014). Peningkatan Kemampuan Berpikir Kritis dan Kreatif Matematis serta Soft Skill Mahasiswa Pendidikan Guru Sekolah Dasar melalui Pendekatan Pembelajaran Kontekstual. Unpublished Dissertation. Bandung: SPs Universitas Pendidikan Indonesia.

Lioe, L.T, Fai, H.K. \& Hedberg, J.G. (2006). Students'metacognitive problem solving strategies in solving openended problems in pairs. [Online]. Diakses dari http://conference.nie.edu.sg/paper/n ew converted/aboo 287.pdf.

Mann, E. L. (2005). Mathematical creativity and school Mathematics: Indicators of mathematical creativity in middle school students. Disertasi University of Connectitut. [Online]. Diakses dari http://www.gifted.uconn.edu/siegle/ Dissertations/Eric\%20Mann.pdf".

Meltzer, D.E. (2002). The relationship between mathematics preparation and conceptual learning gains in physics: a posible "hidden variable" in diagnostic pretest scores. American Journal of Physics, 70(12), 1259-1268. Mittlefehldt, S \& Grotzer, T. (2003). Using metacognition to facilitate the transfer of causal models in learning density and pressure. Presented at the National Association of Research in Science Teaching (NARST) Conference Philadelphia. [Online] Diakses dari
ftp://202.83.110.129/Volume 1/from \%202TB/FAC\%20FOUND\%20STUDIES/ FYLHR9 3/Subject\%20Components/G rey\%20matters/R54ZK1 G/Project\%2 OZero/www.pz.harvard.edu/Research/ UCPpapers/P2NARST03.pdf.

Moma, L., Kusumah, Y.S. Sabandar, J. \& Dahlan, J.A. (2013). The enhancement of junior high school students mathematical creative thinking abilities through Generative learning. Mathematical Theory and Modeling, 3(8), 146-157.

Mullis, I.V.S., Martin O, Michael, Foy, P. \& Arora, A. (2012). TIMSS 2011 international result in Mathematics.TIMSS \&PIRLS international study center lynch school of ed. Boston college, Cheotnut Hill, MA USA and IEA Amsterdam. [Online]. Diakses dari http://timssandpirs.bc.edu/timss2011 /downloads/T11 IR Mathematics Fullbook.pdf.

Munandar, U. (2012). Pengembangan kreativitas anak berbakat. Jakarta: PT Rineka Cipta.

Paris, S. G. \& Winograd, P. (2004). The role of self-regulated learning in contextual teaching: Principles and practices for teacher preparation ${ }^{1[1]}$. [Online] Diakses dari http://www.ciera.org/library/archive/ 200104/ 0104parwin.htm

Rohaeti, E.E. (2010). Critical and creative mathematical thinking of Junior High School student. Educationist Journal, 4(2), 99-106. 
Ruseffendi, E.T. (2006). Pengantar kepada Membantu Guru Mengembangkan Kompetensinya dalam Pengajaran Matematika Untuk Meningkatkan CBSA. Bandung: Tarsito.

Schraw, G., Crippen, K.J, \& Hartley, K. (2006). Promoting self-regulation in Science education: Metacognition as part of a broader perspective on learning. Research in Science Education, 36(1), 111-139.

Starko, A. J. (2010). Creativity in the classroom. New York: Routledge.

Sumarmo, Utari (2013). Kumpulan Makalah Berpikir dan Disposisi Matematik serta Pembelajarannya. Bandung: FPMIPA UPI.

Suwarsono. (2001). Beberapa permasalahan yang terkait dengan upaya implementasi pendidikan matematika realistik di indonesia. Makalah. Disampaikan dalam Seminar Nasional Pendidikan Matematika Realistik di USD, 14-15 November 2001.

Tim MKPBM (2001). Strategi Pembelajaran Matematika Kontemporer. UPI Bandung: JICA.

Treffer (1991). Didactical Background of a Mathemetics program for Primary Education. Dalam Streefland, L. (Ed). Realistic Mathematics Education in Primary School. Utrecht: $\beta$ Press.

Wolters, C. A., Pintrich. P.R., \& Karabenick, S.A. (2003). Assessing academic selfregulated learning. [Online]. Diakses dari http://www.childtrends.org/wpcontent/uploads/2013/05/ Child Trends2003 0312 PD PDConf WPK.pdf
Zumbrunn, S, Tadlock, J., \& Roberts, E.D. (2011). Encouraging Self Regulated Learning in The Classroom: A Review of the Literature. Virginia Commonwealth University. [Online]. Diakses dari http://www.selfregulation.ca/uploads/5/6/2/6/56264 915/encouraging self regulated lear ning in the classroom.pdf.

Zulkardi (2002). Developing a Learning Environment on Realistic Mathematics Education for Indonesian Student Teachers. Thesis University of Twente, Enschede.

Walia, P. (2012). Effect of 5E Instructional Model on Mathematical Creativity of Students. Golden Research Thoughts. $1(\mathrm{X}) .1-4$.

Wijaya, Ariyadi (2012). Pendidikan Matematika Realistik - Suatu Alternatif Pendekatan Pembelajaran Matematika. Yogyakarta: Graha Ilmu.

\section{Riwayat Hidup PenUlis}

Dedi Muhtadi, M.Pd.

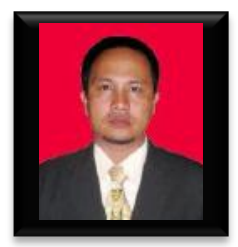

Staf pengajar di Universitas Siliwangi, Tasikmalaya. Studi S3 Pendidikan Matematika Universitas Pendidikan Indonesia, Bandung, sampai dengan sekarang.

Sukirman, M.Si.

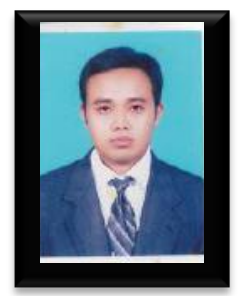

Staf pengajar di Universitas Sultan Ageng Tirtayasa, Banten. Studi S3 Pendidikan Matematika Universitas Pendidikan Indonesia, Bandung, sampai dengan sekarang. 